\title{
First Description of Ecomorphotypes in Seal Subfamilies
}

\author{
Koretsky I, Alexander A and Rahmat SJ* \\ Department of Anatomy, Laboratory of Evolutionary Biology, Howard University \\ College of Medicine, USA
}

*Corresponding author: Sulman Rahmat, Department of Anatomy, Laboratory of Evolutionary Biology, Howard University College of Medicine, 520 W St NW, Washington D.C. 20059, USA, Tel: 2024159904; Email: sulman.rahmat@howard.edu

\section{Research article \\ Volume 3 Issue 1}

Received Date: December 18, 2019

Published Date: January 08, 2020

DOI: $10.23880 /$ izab-16000197

\section{Abstract}

The Family Phocidae consists of four subfamilies, with ecomorphs known only in representatives of the subfamily Phocinae. This study demonstrates that ecological and morphological characters of the other three subfamilies (Cystophorinae, Devinophocinae, Monachinae) do not fit precisely into the previously described ecomorphs for Phocinae. These groupings are based on recent seals, but can also be extrapolated to fossil seals based on morphology and probable ecological preferences. The separation of taxa by combining morphological, ecological and dietary data is extremely important for demonstrating similarities and differences in both fossil and modern representatives of seals of the Family Phocidae, straying away from normal alpha and beta systematics that group species based only on taxonomic relationships. Due to the fragility of cranial remains, the three most commonly found bones (mandible, humerus, femur) are used to group species. Modern seals have specific morphological features and ecological distinctions (diving depths, environment, diet, body size) similar to those of fossil species, providing a rationale for associating the many dissociated fossil elements. For the first time, seals of all phocids subfamilies are divided into their corresponding ecomorphs.

Keywords: Ecomorphotypes; Phocidae; Ecology; Morphology

\section{Introduction}

Based on years of morphological assessment and traditional classification, the Family Phocidae has been divided into three extant subfamilies: Cystophorinae, Monachinae, and Phocinae [1-3], and one extinct subfamily, Devinophocinae [4-6]. There has never been widespread acknowledgment of the aforementioned classification for the extant subfamilies, but researchers such as King, et al., Chapskii, et al. and Koretsky, et al. [79] have all independently found morphological support for these divisions. The number of incisors is one of the most obvious characters to determine sub familial classification (Figure 1). Members of the subfamily 


\section{International Journal of Zoology and Animal Biology}

Cystophorinae have six incisors (2 upper/1 lower), Monachinae have eight incisors $(2 / 2)$, Phocinae have ten incisors (3/2), and Devinophocinae have eight incisors, similar to Monachinae but in a different arrangement (3/1). The extinct subfamily Devinophocinae has unique characters (three-rooted upper M1 and single rooted lower $\mathrm{m} 1$ ) as well as shared characters with the other three extant subfamilies [5,6]. Devinophoca (Figure 2) may be the basic morphotype and represent a primitive relict of the common ancestor of seals [5].

Modern seals are identified by cranial morphology. However, the lack of preserved fossil seal skulls has impeded classification. Therefore, most fossil studies have used dissociated postcranial remains, specifically the humerus and femur (the most commonly found seal bones), for classification [3]. Interpretation of postcranial elements is aided by the analysis of specific ecological niches that are reflected in bone morphology of seals [9]. Recent seals have natural morphological units and specific ecological distinctions (diving depths, environment, diet, body size) that are likely similar to those of fossil species, providing a rationale for associating the many dissociated fossil elements.

The term "ecomorph" has been defined as those species with the same morphology reflecting the same structural habitat/niche [10]. Ecomorphs refer to morphological and behavioral adaptations for a particular niche, with adaptations arising convergently in multiple lineages, similar in morphology and behavior, but not necessarily close phylogenetically. Koretsky's, et al. [9] work on phocine seals used ecomorphotype analysis to assign limb bones and mandibles to individual groups. Due to the lack of preserved phocid cranial material and an abundance of dissociated postcranial remains, ecomorphs are especially important to associate cranial and postcranial bones (Figure 3).

Subfamilial classification is not used to divide seals into ecomorphological groups, instead using dietary preferences, diving depths, body size and bone morphology. In each ecomorphological group of the subfamily Phocinae [9], at least two species are represented, indicating that differing dietary preferences/requirements and specific habitats could allow members of the same subfamily to rest on the same beach and hunt at different depths in the water. In addition, two species of the same genus can share one beach (Figure 4), and be placed into different ecomorphological groups based on bone morphology of the mandible, humerus and femur as well as ecological characters.

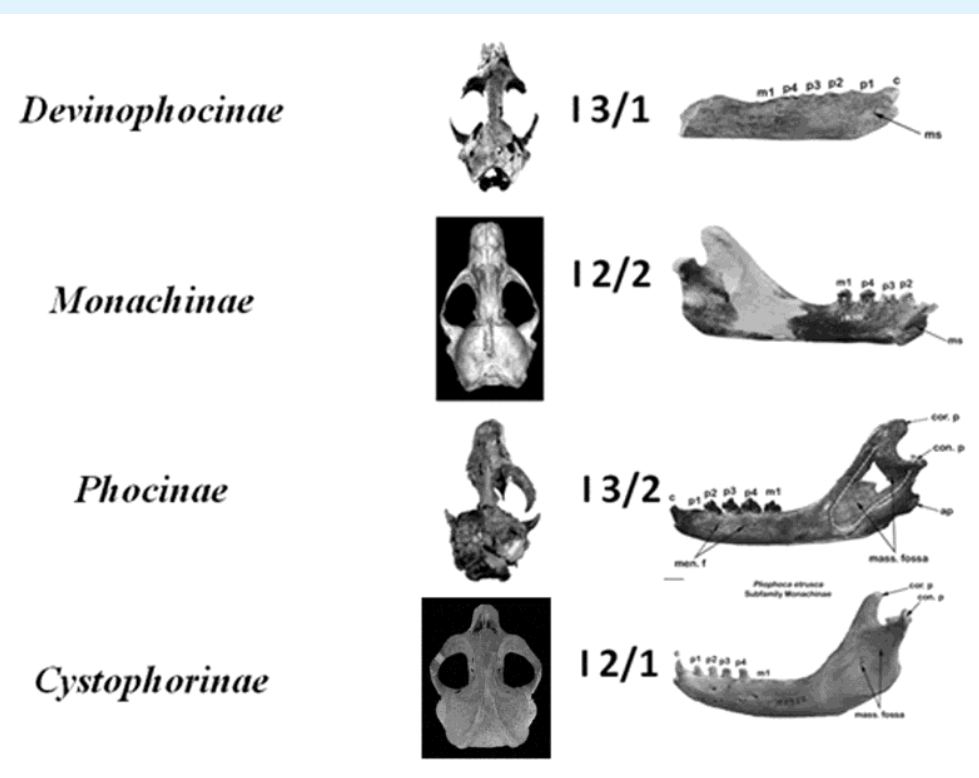

Figure 1: Subfamilial classification of seals based on skull and mandibular morphology and number of incisors. The extinct subfamily Devinophocinae shares characters with the other three subfamilies (same number of incisors as Monachinae in a different arrangement; same number of upper incisors as Phocinae; same number of lower incisors as Cystophorinae). 


\section{International Journal of Zoology and Animal Biology}

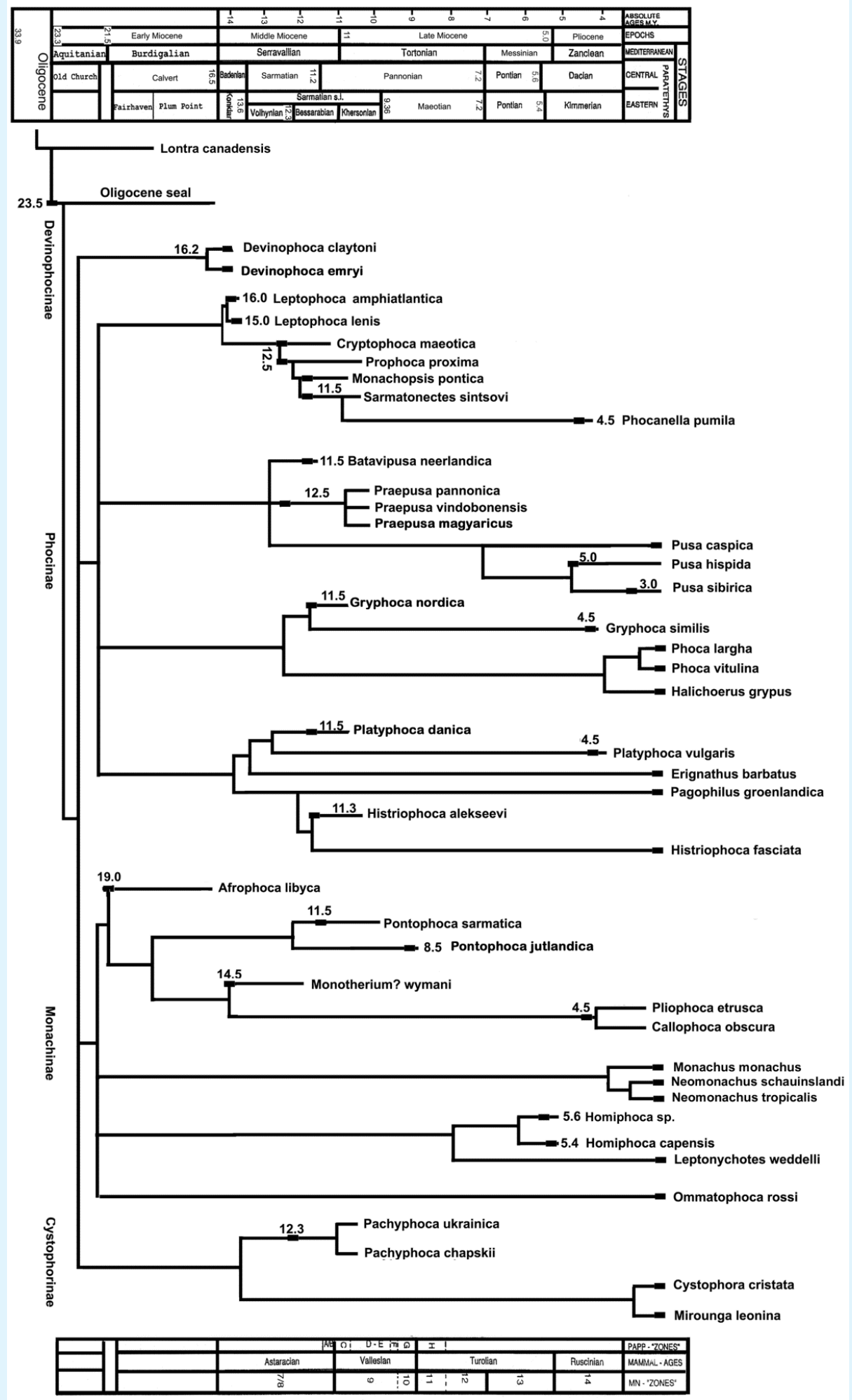

Figure 2: Sub familial tree correlating chronology and stratigraphy of extinct and extant Phocidae. Branching points are not exactly associated with time scale (Updated from Koretsky and Rahmat, 2013). 

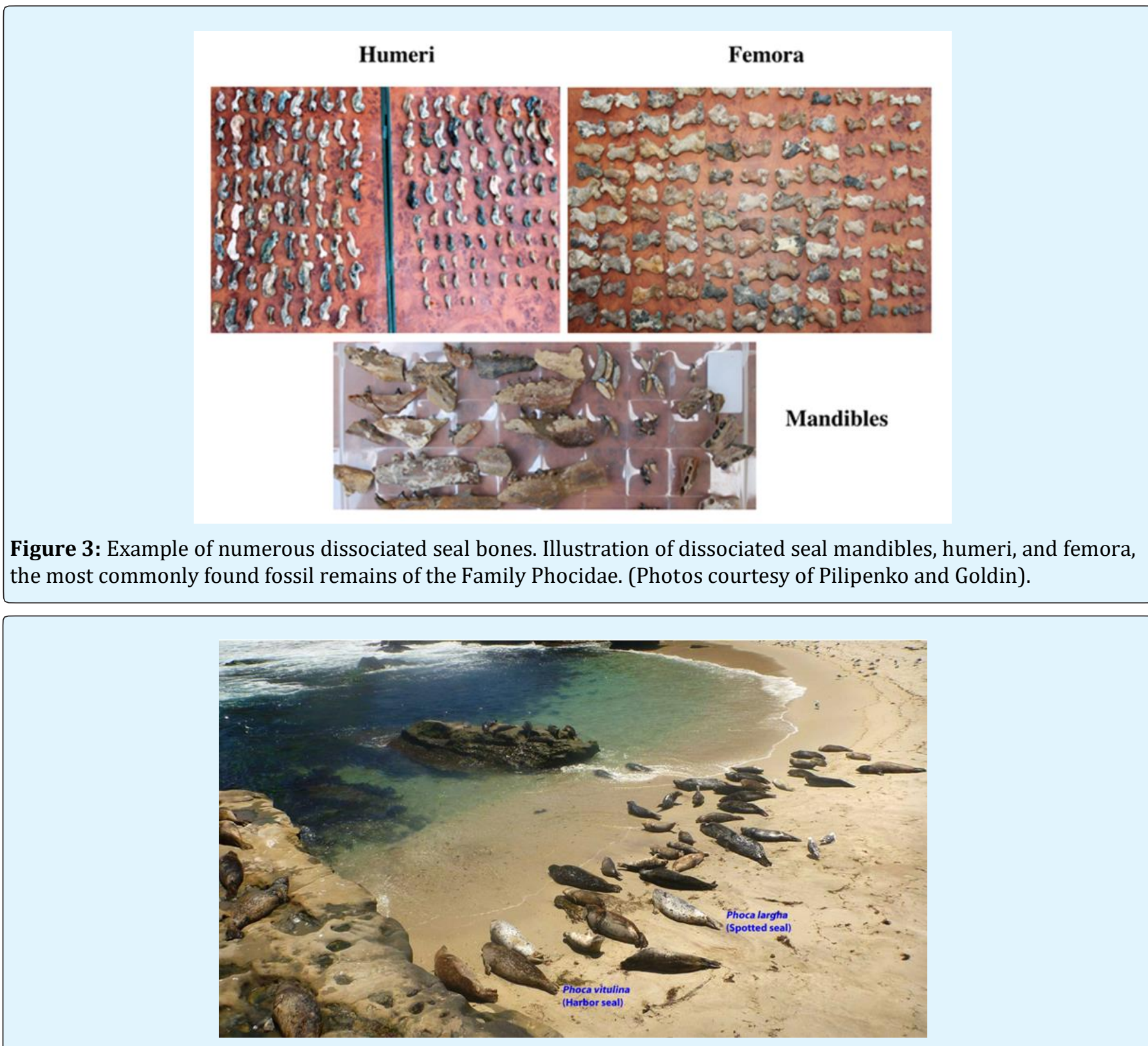

Figure 4: Different species of seals resting on same beach. Different species of seals (Phoca vitulina and Phoca largha) coexisting in the same habitat at La Jolla beach, San Diego, California (USA).

Ecomorphs have been previously demonstrated for only taxa in the extant subfamily Phocinae [9]. This study will determine if representatives of the remaining three seal subfamilies fit into previously described phocine ecomorphological groups. Because of their differences in osteological morphology and ecology (diving depth, diets, habitats), it is hypothesized that seals of the three other subfamilies will not fit precisely into the same phocine ecomorphological groups. If it is found that seals from the other subfamilies fit completely, then specific ecological niches for taxa would not exist. In this scenario, seals living in cold arctic oceans or warm tropical waters would have similar ecology, suggesting that dietary preferences, differences in diving depth and habitat and morphological adaptations are all negligible. However, if seals of the other subfamilies do not fit phocine ecomorphs precisely, then the discovery of additional ecomorphotypes further supports the individual ecological niches of these seals 
and the successful cohabitation within the oceanic food chain. For the first time, morphological specializations and ecological preferences will be examined for each group of seals.

\section{Materials and Methods}

Many fossil specimens were collected over the years during numerous field studies in Europe and North America by Dr. Irina Koretsky from Howard University (USA). The examined specimens for this study are housed in the following institutions: Smithsonian National Museum of Natural History (NMNH) in Washington D.C. (USA); Calvert Marine Museum (CMM) in Maryland (USA); Institute Royal des Sciences Naturelles de Belgique (IRSNB) in Belgium; National Museum of Natural History at the National Academy of Science of Ukraine (NMNHUP) in Kiev (Ukraine); and the Department of Paleontology, Slovakian National Museum (SNMZ) in Bratislava (Slovak Republic). Measurements were taken using fine-toothed calipers, following the methods of Koretsky, et al. and Koretsky, et al. $[9,11]$. An extensive literature search was also conducted to determine ecological specializations, dietary preferences and morphological comparisons.

\section{Ecomorphotypes of Representatives of Family Phocidae}

The Family Phocidae (true seals) has four subfamilies: three extant (Cystophorinae, Monachinae, Phocinae) and one extinct (Devinophocinae). Each subfamily can be identified based on distinguishing morphological characters, mainly from the skull. Prior to this study, ecomorphs have only been studied in the subfamily Phocinae [9]. Therefore, morphological characters of the mandible, humerus and femur of the other three subfamilies will be compared with those already described in phocine seals (Table 1). Detailed below are the cranial characters that place seals into specific subfamilies and not ecomorphological groups.

\begin{tabular}{|c|c|c|c|c|c|}
\hline & & Cystophorinae & Devinophocinae & Monachinae & Phocinae \\
\hline \multirow{4}{*}{ Skull } & Number of Incisors & 6 incisors; $2 / 1$ & 8 incisors; $3 / 1$ & 8 incisors; $2 / 2$ & 10 incisors; $3 / 2$ \\
\hline & $\begin{array}{c}\text { Anterior Palatal } \\
\text { Foramen }\end{array}$ & Oval and shallow & Oval and deep & Tend to disappear & $\begin{array}{c}\text { Well developed with a } \\
\text { groove like shape }\end{array}$ \\
\hline & Interorbital width & $\begin{array}{l}\text { Less than } 30 \% \text { but equal } \\
\text { to or greater than } 25 \% \text { of } \\
\text { mastoid width (widened) }\end{array}$ & $\begin{array}{l}\text { Less than } 30 \% \text { but equal } \\
\text { to or greater than } 25 \% \text { of } \\
\text { mastoid width (widened) }\end{array}$ & $\begin{array}{l}\text { Less widened than } \\
\text { Cystophorinae and } \\
\text { Devinophocinae }\end{array}$ & Narrow \\
\hline & $\begin{array}{c}\text { Preorbital part of } \\
\text { maxilla }\end{array}$ & Narrow concavity & Narrow concavity & Long concavity & Short convexity \\
\hline Mandible & $\begin{array}{l}\text { Mandibular chin } \\
\text { prominence }\end{array}$ & Absent & $\begin{array}{l}\text { D. claytoni present } D \text {. } \\
\text { emryi not present }\end{array}$ & Present & Usually present \\
\hline \multirow{4}{*}{ Humerus } & $\begin{array}{l}\text { Lesser tubercle of } \\
\text { humerus }\end{array}$ & Oval & Flattened, oval & Flattened, square & Pronounced \\
\hline & $\begin{array}{c}\text { Entepicondylar } \\
\text { foramen }\end{array}$ & Present & Present & Present & Varies \\
\hline & $\begin{array}{l}\text { Middle internal crest } \\
\text { of humeral trochlea }\end{array}$ & $\begin{array}{l}\text { Rises wave-like over } \\
\text { coronoid fossa }\end{array}$ & $\begin{array}{l}\text { Located at level of } \\
\text { coronoid fossa }\end{array}$ & $\begin{array}{c}\text { Arch-like and raised } \\
\text { over coronoid fossa }\end{array}$ & $\begin{array}{l}\text { Located at the same } \\
\text { level as coronoid fossa }\end{array}$ \\
\hline & Coronoid Fossa & Oval and shallow & Triangular and deep & $\begin{array}{l}\text { Semicircular and } \\
\text { shallow }\end{array}$ & Triangular and deep \\
\hline \multirow{4}{*}{ Femur } & $\begin{array}{c}\text { Medial and lateral } \\
\text { condyles }\end{array}$ & $\begin{array}{c}\text { Medial condyle } \\
\text { significantly larger than } \\
\text { lateral }\end{array}$ & $\begin{array}{c}\text { Lateral condyle } \\
\text { significantly larger than } \\
\text { medial }\end{array}$ & Almost equal in size & $\begin{array}{c}\text { Lateral condyle } \\
\text { significantly larger } \\
\text { than medial }\end{array}$ \\
\hline & \begin{tabular}{|c|}
$\begin{array}{c}\text { Distal and proximal } \\
\text { epiphyses }\end{array}$ \\
\end{tabular} & $\begin{array}{c}\text { Distal epiphysis larger } \\
\text { than proximal }\end{array}$ & $\begin{array}{c}\text { Proximal epiphysis larger } \\
\text { than distal }\end{array}$ & $\begin{array}{c}\text { Distal epiphysis } \\
\text { larger than proximal }\end{array}$ & $\begin{array}{c}\text { Distal epiphysis larger } \\
\text { than proximal }\end{array}$ \\
\hline & $\begin{array}{c}\text { Intertrochanteric } \\
\text { crest }\end{array}$ & Flat, wide, and thick & Flat and wide & Weakly developed & $\begin{array}{c}\text { Absent or weakly } \\
\text { developed }\end{array}$ \\
\hline & Greater trochanter & $\begin{array}{c}\text { can be U-shaped }\left({ }^{\lambda}\right) \text { or } \\
\text { V-shaped }(q)\end{array}$ & Extends above the head & $\begin{array}{l}\begin{array}{c}\text { Slightly higher than } \\
\text { the head and square }\end{array} \\
\end{array}$ & $\begin{array}{l}\text { Triangular; slightly } \\
\text { higher than the head }\end{array}$ \\
\hline
\end{tabular}

Table 1: Family Phocidae: Subfamilial Comparison of Diagnostic Characters. 


\section{International Journal of Zoology and Animal Biology}

Seals of the subfamily Phocinae have: 10 incisors $(3$ upper and 2 lower); mastoid very pronounced, narrow, cylindrical; mastoid width not greater than half the length of the tympanic (auditory) bulla; bulla directed sharply downward behind the mastoid process; maxilla swollen immediately in front of the orbit, convex, and wide; anterior palatal foramina well developed, with a groovelike shape; mandibular chin prominence present; mandibular symphysis reaches anterior or posterior alveolus of $\mathrm{p} 2$.

Seals of the subfamily Monachinae have: 8 incisors (2 upper and 2 lower); mastoid with wide convexity; convexity not strongly protruding laterally and not turned abruptly downward behind mastoid process; maxilla anterior to orbits slightly concave; anterior palatal foramen tending to disappear; mandibular chin prominence present; posterior mandibular symphysis border reaches at least to middle of alveolus of $\mathrm{p} 3$.

Seals of the subfamily Cystophorinae have: 6 incisors (2 upper and 1 lower); paraoccipital process of skull poorly developed; anteroposterior length of auditory bulla less than the distance between them; infraorbital process present; interorbital space wide (less than 30\% but equal or greater than $25 \%$ of mastoid width); anterior palatal foramina oval and shallow; preorbital part of maxilla with narrow concavity; upper second incisors tend to enlarge rather than first incisors; mandibular chin prominence absent; mandibular symphysis reaches posterior alveolus of $\mathrm{p} 1$.

Seals of the extinct subfamily Devinophocinae have characters shared with the other three subfamilies and have distinguishing characters of their own. Cranial characters include: 8 incisors (similar to Monachinae, but in different order), 3 upper and 1 lower; alveoli of upper incisors form wide u-shaped arc; P2/2-M1/1 doublerooted (as in Cystophorinae, Monachinae, and Phocinae), with posterior root larger than anterior; pre-orbital part of maxilla with wide, pronounced concavity (similar to Monachinae); antorbital process well defined; frontal contact of nasal bone much shorter than maxillary contact (shared with Phocinae); interorbital space slightly broader anteriorly than posteriorly; interorbital width less than $25 \%$ of skull width at mastoid processes (different than Cystophorinae); sagittal crest very well developed (more than in Monachinae), and does not form triangle with lambdoidal crests; diameter of infraorbital foramen less than diameter of alveolus of upper canine (as in Neomonachus schauinslandi) [12], unlike in Cystophorinae and Phocinae); anterior palatal foramina oval and deep, with well-pronounced palatal groove; anteroposterior length of tympanic bullae greater than the distance between them (similar to Cystophorinae and Phocinae); width of mastoid process less than half the length of tympanic bulla; mastoid convexity does not turn ventrally behind mastoid process.

The morphological characters mentioned above divide the Family Phocidae into four subfamilies. Another set of specific characters, not the same characters used for systematic divisions, are used to place representatives of each subfamily into ecomorphological groups. These characters will be demonstrated in this study.

Each Recent species of seal has a specific ecological niche reflected in bone morphology of the cranial and postcranial skeleton. Modern seal classification is mostly based on cranial material. Due to the fragility of skulls in fossil seals, classification has been based mostly on disassociated postcranial bones, mainly the humerus and femur [3]. Lack of preservation is the reason only 15 seal skulls have ever been described in the history of fossil seals. Because the humerus, femur and mandible are the most common dissociated elements of fossil seals, the same bones of modern seals were used to create morphological units. Fossil seal material can be placed into analogous morphological groups with extant seals and the ecology of fossil seals can be extrapolated from what is known in modern seals [9], providing a rationale for associating the many dissociated fossil elements.

According to Koretsky, et al. [9] critical characters for dividing seals into ecomorphotypes include: 1: Mandible: symphyseal form; chin prominence location; height and degree of compression of mandibular body; presence or absence of diastemata; 2: Humerus: ratios of heights of the head and the lesser tubercle; degree of compression of intertubercular groove; location of maximal width of deltoid crest; and 3: Femur: ratios of heights of the head and greater trochanter; greater trochanter shape; location of intertrochanteric crest; and overall shape of femur.

Diving depths, diet, swimming speed, and size of all seals, fossil or modern, can be incorporated into ecomorphotype analysis, placing them into specific groups, independent of sub familial classification. Characters used to place seals into ecomorphological groups are not the same used to identify, describe, or name a species (alpha taxonomy) or classification higher than species level (beta taxonomy). 


\section{International Journal of Zoology and Animal Biology}

\section{Subfamily Phocinae}

There are 5 ecomorphological groups for members of the Subfamily Phocinae based on a study by Koretsky, et al. [9]. Representatives of the First morphological group have worn post-canines from crushing shells, suggesting that they are bottom feeders, feeding on crustaceans, mollusks, and worms approximately 60 to 100 meters deep $[13,14]$. Characters of the mandible include: acute symphyseal part; pronounced and labially bent chin prominence; the chin prominence extends from the alveolus of $\mathrm{p} 2$ to the posterior edge of $\mathrm{p} 4$; maximal height of mandibular body situated between alveoli of $\mathrm{p} 3$ and $\mathrm{p} 4$ or at anterior end of $\mathrm{p} 4$ alveolus; alveoli of teeth shallow; diastemata absent or insignificant; $\mathrm{p} 1$ is single-rooted. Characters of the humerus include: an enlarged lesser tubercle positioned at the level of the head; shallow intertubercular groove; and maximal enlargement of deltoid crest. Characters of the femur include: prominent greater trochanter positioned slightly higher than the head; greater trochanter enlarged in its proximal part and intertrochanteric crest well developed and positioned lower than the head. The extant seal included in the first morphological group is Erignathus barbatus (bearded seal) and an extinct seal representative of this group is Praepusa pannonica.

Representatives of the Second morphological group are mainly predators, piscivorous, and also feed on crustaceans. The post-canines are less worn than in the first group. They feed on fish in large schools in upper layers of the water, but can also dive up to 90 meters $[13,14]$. Characters of the mandible include: acute symphseal part; unpronounced and labially bent chin prominence, positioned at the level between the anterior alveolus of $\mathrm{p} 4$ and posterior alveolus of $\mathrm{m} 1$; maximal height of mandibular body is in the middle of the anterior portion of alveolus $\mathrm{m} 1$; alveoli shallow with small or absent diastemata; p1 may have 2 united roots. Humeral characters include: lesser tubercle positioned higher than the head and extending along the bone's axis; intertubercular groove broad and shallow, and maximal width of deltoid crest is in its proximal part. Femoral characters include: greater trochanter significantly higher than the head; proximal part broader than distal; trochanteric crest weakly developed and ends at the same level as the head. There are several extant seals that fit this ecomorphological group, including: Pusa caspica (Caspian seal), Pusa hispida (ringed seal), Pusa sibirica (Baikal seal), Phoca vitulina (harbor seal), and Pagophilus groenlandicus (harp seal). Based on a weekly pronounced mandibular chin prominence and the maximal height of the mandibular body being located below $\mathrm{m} 1$, one of the extinct seals in this group is Histriophoca alekseevi.

The Third morphological group feed near and on the bottom of the ocean floor, approximately 50-100 meters $[13,14]$, on crabs, shrimp, mollusks, and amphipods, with a portion of their diet also including fish. Their postcanines are much better adapted to eating hard shells than those of the first group. Mandibular characters include: an acute, weakly pronounced symphysis; chin prominence weakly outlined and not bent labially and located beneath the posterior alveoli of $\mathrm{p} 2$ and $\mathrm{p} 4$; maximal height of mandibular body located below $\mathrm{p} 3$ and labially bent; alveoli of teeth shallow and without diastemata, sometimes with united roots. Humeral characters include: lesser tubercle slightly higher than the head and extending along the bone's axis; intertubercular groove not pronounced but instead narrowed; maximal width of the deltoid crest is in its middle or more rarely in its proximal part. Femoral characters include: greater trochanter slightly higher than the head and its proximal part beveled; and a shortened intertrochanteric crest positioned slightly below the trochanteric fossa. Histriophoca fasciata (ribbon seal) is an extant representative of this group, and extinct seals in this group include Sarmatonectes sintsovi, Praepusa vindobonensis, Monachopsis pontica, and Leptophoca lenis.

The Fourth morphological group feeds mainly on large pelagic fishes and to a lesser degree on crustaceans and mollusks. They can dive to depths of 150 to 300 meters $[13,14]$ and feed in both shallow and deep waters. Mandibular characters include: bluntly rounded symphysis; weakly outlined or absent chin prominence; maximal height of mandibular body usually under $\mathrm{p} 4$; alveoli of teeth rounded and large with equal diastemata between them; p1 single- or double-rooted; p2 singlerooted. Humeral characters include: rounded lesser tubercle positioned considerably higher than head; intertubercular groove small and not deep and maximal width of deltoid crest uniform along its length. Femoral characters include: greater trochanter located much higher than head, with a widened proximal part; intertrochanteric crest reaches level of head and oriented transverse to the bone's axis.

Extant seals in the fourth morphological group include Phoca largha (spotted seal) and Halichoerus grypus (grey seal). Despite having limb bones morphologically similar to the extant species, the extinct species "Phoca" bessarabica has distinguishable, short, bulbous limb bones. 


\section{International Journal of Zoology and Animal Biology}

The Fifth morphological group is only represented by the fossil species Cryptophoca maeotica. Mandibular characters include: thickened, straight symphysis; weak chin prominence that is not bent labially; chin prominence located below the interval from anterior alveolus of $\mathrm{p} 3$ to posterior alveolus of $\mathrm{p} 4$; maximal height of mandibular body located below alveoli p3-p4; alveoli small with large diastemata; p1 single-rooted, with small alveoli. Humeral characters include: an oval lesser tubercle approximately equal in size to the head; unpronounced intertubercular groove; and the maximal width of deltoid crest is in the proximal part. Femoral characters include: greater trochanter positioned much higher than head and nearly rectangular in cross-section; intertrochanteric crest positioned below trochanteric fossa and located on middle axis of bone.

The fifth phocine ecomorphological group has no living representative, reflecting the much broader diversity of fossil seals than in modern times. Ecomorphological groups supplement sub familial classification and use bone morphology and ecology to place species in functional, $\gamma$-taxonomic groups, alongside the usual $\alpha$ - and $\beta$-taxonomy. Members of the subfamilies Cystophorinae, Devinophocinae and Monachinae will not fit perfectly into the ecomorphological groups described for Phocinae, but key ecological and morphological characters will be used to place species of the other subfamilies into analogous groups.

\section{Results}

\section{Subfamily Monachinae}

Ecomorphological comparisons of the subfamilies Cystophorinae, Devinophocinae, Monachinae, and Phocinae demonstrate specific characters used to place representatives into ecomorph groups, with some taxa possibly belonging somewhere between the described phocine groups. Characters of the mandible, humerus and femur of representatives of monachine seals do not fit into one specific ecomorphotype, as they did in Phocinae. Each species of the subfamily Monachinae has a commonality with at least one of the phocine groups, but none exhibits characters placing the mandible, humerus, and femur all in the same group.

Based on the characters discussed above for ecomorphs analysis of Phocinae, the Recent monachine seal Monachus monachus should be placed into ecomorph 3 based on the mandibular chin prominence being weakly pronounced and extending from p2-p4. It could be placed into ecomorph 1 due to the maximal enlargement of the humeral deltoid crest being found in the middle of the bone, or ecomorph 2 because of the weakly developed femoral intertrochanteric crest (Table 2). Based on ecology, the Mediterranean monk seal should be placed into ecomorph group 2, as Monachus monachus feeds on fish and crustaceans in upper layers of water and can dive to up to 196 meters [15].

\begin{tabular}{|c|c|c|}
\hline & Phocinae & Monachinae \\
\hline \multirow{2}{*}{ Group 1 of Phocinae } & Erignathus barbatus & \multirow{2}{*}{ Monachus monachus } \\
\hline & † Praepusa pannonica & \\
\hline \multirow{4}{*}{ Group 2 of Phocinae } & Phoca vitulina & + Callophoca obscura \\
\hline & Pagophilus groenlandica & Monachus monachus \\
\hline & † Histriophoca alekseevi & \\
\hline & Pusa caspica & \\
\hline \multirow{5}{*}{ Group 3 of Phocinae } & Histriophoca fasciata & † Pliophoca etrusca \\
\hline & + Praepusa vindobonensis & + Pontophoca sarmatica \\
\hline & t Leptophoca lenis & Monachus monachus \\
\hline & † Monachopsis pontica & \\
\hline & + Sarmatonectes sintsovi & \\
\hline \multirow{3}{*}{ Group 4 of Phocinae } & Phoca largha & + Callophoca obscura \\
\hline & Halichoerus grypus & † Pliophoca etrusca \\
\hline & † Phoca bessarabica & \\
\hline \multirow{2}{*}{ Group 5 of Phocinae } & \multirow{2}{*}{ +Cryptophoca maeotica } & + Pontophoca sarmatica \\
\hline & & † Pliophoca etrusca \\
\hline
\end{tabular}

Table 2: Phocinae Ecomorphs vs. Members of Subfamily Monachinae. 


\section{International Journal of Zoology and Animal Biology}

Morphological characters of fossil representatives will also be examined to place into corresponding ecomorph groups. The extinct monachine Callophoca obscura (early Pliocene, $\sim 5.3-3.0 \mathrm{Ma}$ ) should be placed in phocine group 4 based on mandibular (round alveoli and absent chin prominence) and femoral (wide, elongated proximal part of the greater trochanter, and intertrochanteric crest not reaching the midline) characters. However, the presence of a wide and shallow humeral intertubercular groove places Callophoca obscura into phocine ecomorph 2. The extinct monachine Pliophoca etrusca (early Pliocene, 5.3-2.6 Ma) should be placed into ecomorph 3 based on the location of the mandibular chin prominence at $\mathrm{p} 3$ and the height of the femoral greater trochanter. Humeral characters can place Pliophoca etrusca into either ecomorph 4 (spherical lesser tubercle of the humerus) or group 5 (shape of the humeral lesser tubercle and also similar heights of the lesser tubercle and the head).

The extinct monachine Pontophoca sarmatica (middle Miocene, $12.7-11.6 \mathrm{Ma}$ ) appears to belong to ecomorph 5 based on the large diastemata found on the mandible, as well as the femoral greater trochanter being situated higher than the head and the trochanteric fossa being located on the middle axis of the bone. However, Pontphoca sarmatica could also be placed into group 3 based on location of the humeral lesser tubercle slightly higher than the head and its extension along the bone's axis.

Furthermore, a new member of this subfamily, Afrophoca libyca (early Miocene, $19 \mathrm{Ma}$ ), one of the oldest seals ever described, should be included in group 1 based on the absence of diastemata and presence of a mandibular chin prominence. Only the mandible of Afrophoca libyca has been described so far [16].

Members of the subfamily Monachinae have more morphological commonalities with Phocinae than with Cystophorinae, but not as many with Devinophocinae. None of the aforementioned species for members of subfamily Monachinae were all placed in the same phocine ecomorph group based on characters of the mandible, humerus, and femur taken together. At most, 2 of the 3 bones (in different combinations) may fall into one phocine group with one matching another group (Table 2). Members of subfamily Monachinae are the only seals consistently found in and around the tropical belt, allowing their diet to be much more diversified, due to the lack of competition from other seals.

\section{Subfamily Cystophorinae}

Morphological characters of the extant Mirounga angustirostris (Northern elephant seal) and Cystophora cristata (hooded seal) and the extinct Pachyphoca ukrainica, all representatives of the subfamily Cystophorinae, do not fit into any specific ecomorphological group described above.

The extant members of the subfamily Cystophorinae display the most obvious sexual dimorphism among the four phocid subfamilies. Mirounga angustirostris and Cystophora cristata could each be divided into separate ecomorphological groups using characters that differ for each gender. Mirounga angustirostris could be placed into: 1) phocine ecomorph 3 due to the weakly outlined mandibular chin prominence in males; 2) phocine ecomorph 2 based on the wide and shallow humeral intertubercular groove in females; 3 ) phocine ecomorph 5 because of the oval-shaped lesser tubercle and absent intertubercular groove in males; 4) phocine ecomorph 1 or 4 because in males the maximal width of the femoral greater trochanter is found in its proximal part. Based on ecology, both male and female Mirounga angustirostris belong in ecomorph group 4, as M. angustirostris feeds on mesopelagic fish and are the deepest divers among seals (maximum diving depth 1700 meters).

Based solely on bone morphology, neither male nor female Cystophora cristata fit into any of the previously defined phocine ecomorphological groups (Table 3). Cystophora cristata feeds on prey similar to phocine ecomorph groups 3 and 4 including: pelagic fish, shrimp, mollusks, and amphipods (group 3 only). The optimal diving depth of a hooded seal is $100-600$ meters $[13,14]$, which overlaps with both phocine ecomorphs 3 and 4 . Based on ecology, both male and female $C$. cristata belong between ecomorphs 3 and 4. Similar to representatives of the subfamily Monachinae, characters of the mandible, humerus and femur do not all fit one specific ecomorphotype as they did in Phocinae. These seals likely belong somewhere between the described phocine groups.

For the extinct Pachyphoca ukrainica (middle Miocene, 12.3-11.2 Ma; Koretsky, et al. [3], no mandibles have been described. Humeral characters of Pachyphoca ukrainica do not fit completely into one ecomorphological group, opposite to the condition in Phocinae. These characters include: a wide and shallow intertubercular groove (ecomorphotype 2 in Phocinae) and the maximal enlargement of the deltoid crest being found in the middle 
(ecomorphotype 1 in Phocinae). In addition, the proximal part of the femoral greater trochanter is wider than the distal part (ecomorphotype 2 in Phocinae). The lack of a described mandible and the inability to place humeral and femoral characters into one ecomorphological group demonstrates that $P$. ukrainica may belong somewhere between phocine ecomorphological groups 1 and 2 (Table $3)$.

\begin{tabular}{|c|c|c|}
\hline & Phocinae & Cystophorinae \\
\hline \multirow{2}{*}{ Group 1 of Phocinae } & Erignathus barbatus & † Pachyphoca ukrainica \\
\hline & † Praepusa pannonica & Mirounga angustirostris \\
\hline \multirow{4}{*}{ Group 2 of Phocinae } & Phoca vitulina & † Pachyphoca ukrainica \\
\hline & Pagophilus groenlandica & Mirounga angustirostris \\
\hline & $\dagger$ Histriophoca alekseevi & \\
\hline & Pusa caspica & \\
\hline \multirow{5}{*}{ Group 3 of Phocinae } & Histriophoca fasciata & Cystophora cristata \\
\hline & + Praepusa vindobonensis & Mirounga angustirostris \\
\hline & † Leptophoca lenis & \\
\hline & † Monachopsis pontica & \\
\hline & + Sarmatonectes sintsovi & \\
\hline \multirow{3}{*}{ Group 4 of Phocinae } & Phoca largha & Cystophora cristata \\
\hline & Halichoerus grypus & Mirounga angustirostris \\
\hline & + Phoca bessarabica & \\
\hline Group 5 of Phocinae & + Cryptophoca maeotica & Mirounga angustirostris \\
\hline
\end{tabular}

Table 3: Phocinae Ecomorphs vs. Members of Subfamily Cystophorinae.

Members of the subfamily Cystophorinae had the least in common with the five phocine ecomorphological groups and were difficult to place. Many of the characters available for examination were not comparable to the characters used for the other three subfamilies. This is not a surprise since cystophorine seals exhibit a mosaic of characters, with some derived and others more primitive. The characters reflect extreme sexual dimorphism along with distinct dietary differences creating a unique cystophorine ecomorphotype. Based solely on diet and diving depth, comparisons among specific phocine ecomorphotypes could be made, but functional morphology for the cystophorine ecomorphotype was not helpful in drawing those conclusions. Therefore, extending these observations from extant cystophorine seals to fossils requires a different set of characters.

\section{Subfamily Devinophocinae}

Devinophoca emryi and Devinophoca claytoni, both extinct sister taxa and the only members of the subfamily Devinophocinae, were also placed into ecomorphological groups. For D. claytoni, only the skull and mandible have been described, while for $D$. emryi a skull, mandible, and postcranial material are known. D. claytoni should be placed in phocine ecomorph group 1 based on the presence of a mandibular chin prominence and the absence of diastemata between teeth. D. emryi should be placed in phocine ecomorph 3 based on the characters of the mandible (no diastemata; sometimes the teeth have united roots), the humerus (the lesser tubercle is positioned slightly higher than the head; the maximal width of the deltoid crest is in the middle) and the femur (the greater trochanter is positioned higher than the head).

Characters of the mandible, humerus and femur of $D$. emryi (Figure 5) all fit into one specific ecomorphotype, as they did in Phocinae. Members of the Subfamily Devinophocinae have unique characters as well as characters shared with the other three extant subfamilies, possibly being the closest to a common morphotype for the Family Phocidae (Koretsky and Holec, 2002; Koretsky and Rahmat, 2015; Rahmat and Koretsky, 2016; Rahmat and Koretsky, 2018). Since D. claytoni and D. emryi are not in the same ecomorphotype group, other newly found species of Devinophocinae may fit some of the other 3 ecomorph groups described for members of the subfamily Phocinae. The current finding that D. emryi is the only member of a subfamily outside of Phocinae that has characters of all three bones (mandible, humerus, and femur) fit in one ecomorph group (Table 4) is further evidence that the subfamily Devinophocinae comes the closest to an ancestral morphotype. 


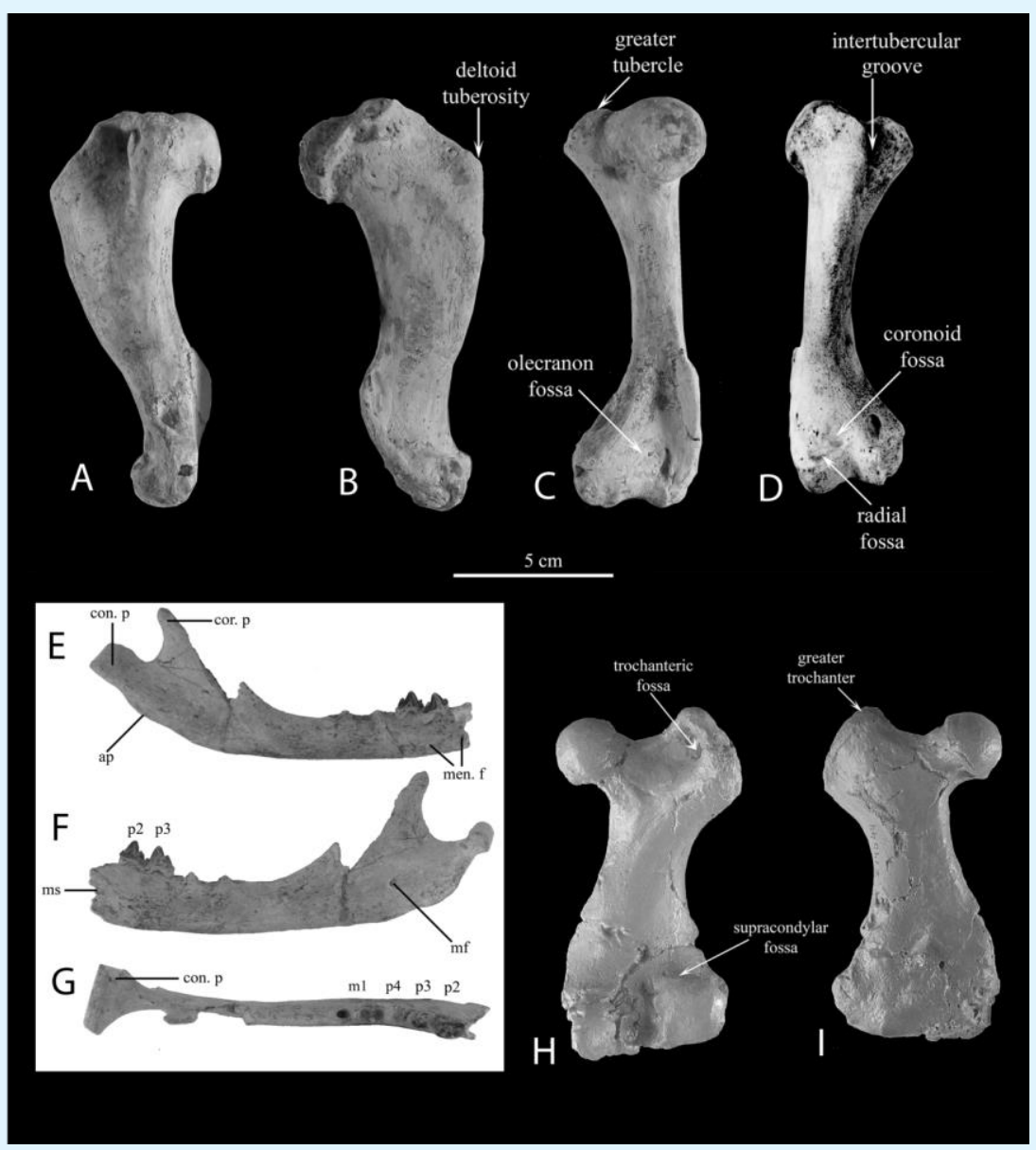

Figure 5: Cranial and postcranial association of extinct subfamily Devinophocinae. Mandible, humerus, and femur of Devinophoca emryi of the extinct subfamily Devinophocinae (Modified from Rahmat and Koretsky, 2016).

\begin{tabular}{|c|c|c|}
\hline & Phocinae & Devinophocinae \\
\hline \multirow{2}{*}{ Group 1 of Phocinae } & Erignathus barbatus & \multirow{2}{*}{ † Devinophoca claytoni } \\
\hline & † Praepusa pannonica & \\
\hline \multirow{4}{*}{ Group 2 of Phocinae } & Phoca vitulina & \multirow{9}{*}{ † Devinophoca emryi } \\
\hline & Pagophilus groenlandica & \\
\hline & † Histriophoca alekseevi & \\
\hline & Pusa caspica & \\
\hline \multirow{5}{*}{ Group 3 of Phocinae } & Histriophoca fasciata & \\
\hline & † Praepusa vindobonensis & \\
\hline & † Leptophoca lenis & \\
\hline & † Monachopsis pontica & \\
\hline & † Sarmatonectes sintsovi & \\
\hline \multirow{3}{*}{ Group 4 of Phocinae } & Phoca largha & \\
\hline & Halichoerus grypus & \\
\hline & + Phoca bessarabica & \\
\hline Group 5 of Phocinae & +Cryptophoca maeotica & \\
\hline
\end{tabular}

Table 4: Phocinae Ecomorphs vs. Members of Subfamily Devinophocinae. 
The mandible, humerus, and femur of Devinophoca emryi fit into phocine ecomorph group three, but the mandible of $D$. claytoni (postcranial material yet unknown) fit into phocine ecomorph group one. Based on the morphological assessment of this study, the future discovery of D. claytoni postcranial fossil elements will likely also place it in ecomorph one. The ecomorphotype analysis of devinophocine seals supports the previous proposal [4,11,] that they are the closest common morphotype for the Family Phocidae and share similar morphological characters with representatives of the remaining subfamilies [17]. The finding of D. claytoni and $D$. emryi fossil elements at the same locality within the same geologic timeframe, and the fact that they belong in separate ecomorphological groups, further supports that these extinct species had different dietary preferences and diving abilities to coexist successfully with one another. Clear differences in diving depths, body size and bone morphology result in diminished dietary competition amongst seals and explain how they can coexist on the same beach and habitat.

\section{Conclusion}

Seals of different species are known to share the same beach and surrounding waters (Figure 4). The reason why different species can coexist in a shared habitat is because different diets and diving depths eliminate competition for food. For example: 1) representatives of phocine ecomorph one are bottom feeders, feeding on crustaceans, mollusks, and worms at a depth of approximately 60 meters; 2) representatives of phocine ecomorph two (i.e. Phoca vitulina) feed on fish in large schools approximately 90 meters deep and in upper layers of the water, also on crustaceans; and 3) representatives of phocine ecomorph four (i.e. Phoca largha) feed mainly on large pelagic fishes and to a lesser degree on crustaceans and mollusks approximately 150 to
300 meters deep and in shallow water. The contrasting diets among these three ecomorphological groups minimize competition between sympatric species, substantiating how all three groups could live in the same habitat $[18,19]$.

This study is the first to place seals of all four subfamilies into specific ecomorphotype groups (Tables 5\&6). These new groupings for the subfamilies Cystophorinae and Monachinae are based on recent seal data, but can also be extrapolated to fossil seals based on morphology and possible ecological preferences. The characterization of taxa by combining morphological, ecological and dietary data is extremely important for demonstrating similarities and differences in both fossil and modern representatives of the Family Phocidae, supplementing normal alpha and beta systematics that group species based only on taxonomic relationships.

Knowledge of the ecology of modern seals helps provide a rationale for determining the likely ecology for their fossil counterparts. Differences in diving depth and diet are mirrored in the morphology for both modern and extinct species. Ecomorph examination of the mandible, humerus, and femur of members of the subfamily Phocinae has already been documented in Koretsky's, et al. [9] study, but the other three subfamilies had not been examined using ecomorphological analysis prior to this study. The phocine ecomorph groups were used as a template to create new ecomorphological groups for representatives, both modern and fossil, of the subfamily Cystophorinae (Table 5) and subfamily Monachinae (Table 6). Because members of the subfamily Cystophorinae have well-established sexually dimorphic features, both morphological and dietary differences/specializations were incorporated when creating the new ecomorph groups (Table 5).

\begin{tabular}{|c|c|c|c|c|c|}
\hline comorph & \multicolumn{3}{|c|}{ Characters } & \multirow[t]{2}{*}{ Species } & \multirow[t]{2}{*}{ Ecology } \\
\hline & Mandible & Humerus & Femur & & \\
\hline 1A & $\begin{array}{l}\text { diastemata } \\
\text { present; } \\
\text { small, } \\
\text { compressed } \\
\text { mandibular } \\
\text { body; chin } \\
\text { prominence } \\
\text { absent }\end{array}$ & $\begin{array}{l}\text { maximal enlargement } \\
\text { of deltoid crest in } \\
\text { middle part; } \\
\text { elongated deltoid } \\
\text { crest reaching past } \\
\text { middle of bone; } \\
\text { elongated lesser } \\
\text { tubercle extending } \\
\text { along bone axis; wide } \\
\text { and shallow }\end{array}$ & $\begin{array}{l}\text { greater trochanter } \\
\text { lower than head; } \\
\text { maximal width of } \\
\text { greater trochanter in } \\
\text { proximal part; short } \\
\text { intertrochanteric crest }\end{array}$ & $\begin{array}{l}F \text { - Mirounga } \\
\text { angustirostris }\end{array}$ & $\begin{array}{c}\text { feed on rockfish, squid, } \\
\text { midshipman, octopus, } \\
\text { Pacific lamprey, hagfish } \\
\text { and small sharks; diet } \\
\text { consists of more } \\
\text { mesopelagic squid and } \\
\text { less fish; diving depth is } \\
\text { 350-650 m, with a } \\
\text { maximum depth of } 1273 \\
\text { m }\end{array}$ \\
\hline
\end{tabular}




\begin{tabular}{|c|c|c|c|c|c|}
\hline & & $\begin{array}{c}\text { intertubercular } \\
\text { groove }\end{array}$ & & & \\
\hline 1B & $\begin{array}{l}\text { diastemata } \\
\text { present; } \\
\text { large, robust } \\
\text { mandubular } \\
\text { body; } \\
\text { weakly } \\
\text { developed } \\
\text { chin } \\
\text { prominence }\end{array}$ & $\begin{array}{l}\text { maximal enlargement } \\
\text { of deltoid crest in } \\
\text { middle part; } \\
\text { elongated deltoid } \\
\text { crest reaching past } \\
\text { middle of bone; lesser } \\
\text { tubercle significantly } \\
\text { higher than head and } \\
\text { oval shaped; absent } \\
\text { intertubercular } \\
\text { groove }\end{array}$ & $\begin{array}{l}\text { greater trochanter } \\
\text { lower than head; } \\
\text { maximal width of } \\
\text { greater trochanter in } \\
\text { proximal part; short } \\
\text { intertrochanteric crest }\end{array}$ & $\begin{array}{l}\text { M-Mirounga } \\
\text { angustirostris }\end{array}$ & $\begin{array}{l}\text { feed on rockfish, squid, } \\
\text { midshipman, octopus, } \\
\text { Pacific lamprey, hagfish } \\
\text { and small sharks; diet } \\
\text { consists more of bottom } \\
\text { feeders, including fish, } \\
\text { mollusks, crustaceans and } \\
\text { other shelled vertebrates } \\
\text { (more weakened } \\
\text { dentition compared to } \\
\text { females); diving depth is } \\
450-1250 \text { m, with a } \\
\text { maximum depth of } 1530 \\
\text { m }\end{array}$ \\
\hline $2 A$ & $\begin{array}{l}\text { diastemata } \\
\text { present; } \\
\text { shorter } \\
\text { mandibular } \\
\text { body; } \\
\text { absent chin } \\
\text { prominence }\end{array}$ & $\begin{array}{l}\text { short, narrow deltoid } \\
\text { crest ends distally in } \\
\text { V-shape; lesser } \\
\text { tubercle higher than } \\
\text { head; wide } \\
\text { intertubercular } \\
\text { groove Well } \\
\text { developed deltoid } \\
\text { tuberosity }\end{array}$ & $\begin{array}{c}\text { greater trochanter } \\
\text { short and narrow, } \\
\text { terminates in V shape; } \\
\text { lesser trochanter not } \\
\text { well developed Greater } \\
\text { trochanter terminates } \\
\text { V-shape }\end{array}$ & $\begin{array}{c}\text { F- Cystophora } \\
\text { cristata }\end{array}$ & $\begin{array}{l}\text { diet of halibut, Greenland } \\
\text { cod, herring, flounder, } \\
\text { octopus, shrimp, squid } \\
\text { and mussels; dive up to } \\
180 \mathrm{~m}\end{array}$ \\
\hline 2B & $\begin{array}{l}\text { diastemata } \\
\text { present; } \\
\text { higher } \\
\text { mandibular } \\
\text { body; } \\
\text { absent chin } \\
\text { prominence }\end{array}$ & $\begin{array}{l}\text { elongate, wide deltoid } \\
\text { crest ends distally in } \\
\text { U-shape; lesser } \\
\text { tubercle higher than } \\
\text { head and spherical in } \\
\text { shape; narrow } \\
\text { intertubercular } \\
\text { groove }\end{array}$ & $\begin{array}{l}\text { greater trochanter } \\
\text { wide and long, } \\
\text { terminates in U shape; } \\
\text { lesser trochanter } \\
\text { present, well } \\
\text { developed; }\end{array}$ & $\begin{array}{c}M- \\
\text { Cystophora } \\
\text { cristata }\end{array}$ & same as females \\
\hline 3 & $\mathrm{~N} / \mathrm{A}$ & $\begin{array}{l}\text { maximal enlargement } \\
\text { of the deltoid crest } \\
\text { being found in the } \\
\text { middle; lesser } \\
\text { tubercle lower than } \\
\text { head; a wide and } \\
\text { shallow } \\
\text { intertubercular } \\
\text { groove }\end{array}$ & $\begin{array}{l}\text { greater trochanter } \\
\text { slightly higher than } \\
\text { head and proximal part } \\
\text { is wider than distal; } \\
\text { flat, wide and thick } \\
\text { intertrochanteric crest; } \\
\text { lesser trochanter thick, } \\
\text { not separated from } \\
\text { intertrochanteric crest }\end{array}$ & $\begin{array}{c}\text { †Pachyphoca } \\
\text { ukrainica }\end{array}$ & $\mathrm{N} / \mathrm{A}$ \\
\hline
\end{tabular}

Table 5: Subfamily Cystophorinae Ecomorphs.

\begin{tabular}{|c|c|c|c|c|c|}
\hline Ecomorph & \multicolumn{3}{|c|}{ Characters } & \multirow[t]{2}{*}{ Species } & \multirow[t]{2}{*}{ Ecology } \\
\hline & Mandible & Humerus & Femur & & \\
\hline 1 & $\begin{array}{l}\text { chin } \\
\text { prominence } \\
\text { weakly } \\
\text { pronounced; } \\
\text { diastemata }\end{array}$ & $\begin{array}{l}\text { maximal enlargement of the } \\
\text { deltoid crest found in the } \\
\text { middle; lesser tubercle at } \\
\text { same level as head and } \\
\text { spherical in shape; shallow }\end{array}$ & $\begin{array}{l}\text { greater trochanter at } \\
\text { same level as head; } \\
\text { shape of greater } \\
\text { trochanter more } \\
\text { rectangular; weakly }\end{array}$ & $\begin{array}{c}\text { Monachus } \\
\text { monachus } \\
\text { †Pliophoca } \\
\text { etrusca }\end{array}$ & $\begin{array}{l}\text { diet of fish and } \\
\text { crustaceans in } \\
\text { upper layers } \\
\text { of water; } \\
\text { maximum }\end{array}$ \\
\hline
\end{tabular}




\section{International Journal of Zoology and Animal Biology}

\begin{tabular}{|c|c|c|c|c|c|}
\hline & $\begin{array}{l}\text { absent; } \\
\text { symphysis } \\
\text { reaches } \\
\text { anterior } \\
\text { alveolus of p3 }\end{array}$ & intertubercular groove & $\begin{array}{c}\text { developed } \\
\text { intertrochanteric crest }\end{array}$ & & $\begin{array}{l}\text { diving depth is } \\
196 \mathrm{~m}\end{array}$ \\
\hline 2 & $\begin{array}{l}\text { chin } \\
\text { prominence } \\
\text { weakly } \\
\text { pronounced; } \\
\text { diastemata } \\
\text { present but } \\
\text { irregular; thick } \\
\text { symphysis }\end{array}$ & $\begin{array}{l}\text { maximal enlargement of } \\
\text { deltoid crest found in } \\
\text { proximal end of bone, not } \\
\text { reaching middle; lesser } \\
\text { tubercle higher than head; } \\
\text { lesser tubercle flattened and } \\
\text { oval shaped; wide and } \\
\text { shallow intertubercular } \\
\text { groove }\end{array}$ & $\begin{array}{l}\text { greater trochanter } \\
\text { situated below head; } \\
\text { wide proximal part of } \\
\text { greater trochanter; } \\
\text { shortened, well- } \\
\text { develped } \\
\text { intertochanteric crest }\end{array}$ & $\begin{array}{c}\text { †Callophoca } \\
\text { obscura }\end{array}$ & $\mathrm{N} / \mathrm{A}$ \\
\hline 3 & $\begin{array}{c}\text { large } \\
\text { diastemata }\end{array}$ & $\begin{array}{l}\text { maximal enlargement of } \\
\text { deltoid crest found in } \\
\text { proximal end of bone; lesser } \\
\text { tubercle lower than head } \\
\text { and ; shortened deltoid crest } \\
\text { ending in middle of bone; } \\
\text { intertubercular groove } \\
\text { absent }\end{array}$ & $\begin{array}{l}\text { greater trochanter } \\
\text { higher than head; } \\
\text { greater trochanter distal } \\
\text { end v-shaped; } \\
\text { elongated, wide } \\
\text { intertrochanteric crest } \\
\text { reaching middle of shaft }\end{array}$ & $\begin{array}{c}\text { +Pontophoca } \\
\text { sarmatica }\end{array}$ & $\mathrm{N} / \mathrm{A}$ \\
\hline 4 & $\begin{array}{c}\text { stongly } \\
\text { developed chin } \\
\text { prominence; } \\
\text { diastemata } \\
\text { absent }\end{array}$ & $\mathrm{N} / \mathrm{A}$ & $\mathrm{N} / \mathrm{A}$ & $\begin{array}{c}\text { tAfrophoca } \\
\text { libyca }\end{array}$ & $\mathrm{N} / \mathrm{A}$ \\
\hline
\end{tabular}

Table 6: Subfamily Monachinae Ecomorphs.

Evidence of ecomorphological grouping in seals demonstrates the importance of ecological and morphological correlation in modern and fossil species. Since Koretsky's, et al. [9] ecomorph study on phocine seals, other groups of animals (i.e. finches, lizards, rabbits) have also been described to have specific morphological and ecological associations, further supporting the results of this study.

\section{Acknowledgements}

We want to thank Global Dimensions, LLC for supporting our research. We want to thank the reviewers and editor(s) for their suggestions and comments, further strengthening our manuscript.

\section{References}

1. Gray JE (1875) The zoology of the Voyage of H.M.S. Erebus \& Terror, Under the Command of Captain Sir James Clark Ross, N.N., F.R.S., During the years 1839 to 1843. London.
2. Trouessart EL (1897) Carnivora, Pinnipedia, Rodentia I. Fascicle II. In: Catalogus mammalium tam viventium quam fossilium. Nova editio. R. Friedländer \& Sohn, Berlin pp: 452.

3. Koretsky IA, Rahmat SJ (2013) First Record of Fossil Cystophorinae (Carnivora, Phocidae): Middle Miocene Seals from the Northern Paratethys. Rivista Italiana di Paleontologia e Stratigrafia 119(3): 325350.

4. Koretsky IA, Holec P (2002) A primitive Seal (Mammalia: Phocidae) from the Early Middle Miocene of Central Paratethys. Smithsonian Contributions to Paleobiology 93: 163-178.

5. Koretsky IA, Rahmat SJ (2015) A New Species of the Subfamily Devinophocinae (Carnivora, Phocidae) from the Central Paratethys. Rivista Italiana di Paleontologia e Stratigrafia 121(1): 31-47.

6. Rahmat SJ, Koretsky IA (2016) First Record of Postcranial Bones in Devinophoca emryi (Carnivora, 


\section{International Journal of Zoology and Animal Biology}

Phocidae, Devinophocinae). Vestnik Zoologii 50(1): 71-86.

7. King JE (1964) Seals of the World. British Museum of Natural History. London, England pp: 154.

8. Chapskii KK (1974) In defense of classical taxonomy of the seals of the family Phocidae. Trudy Zool Inst Akad Sci 53: 282-334.

9. Koretsky IA (2001) Morphology and systematics of Miocene Phocinae (Mammalia: Carnivora) from Paratethys and the North Atlantic region. Budapest: Geological Institute of Hungary 54: 1-109.

10. Williams EE (1972) The origin of faunas. Evolution of lizard congeners in a complex island fauna: a trial analysis. Evolutionary Biology 6: 47-89.

11. Koretsky IA, Ray CE (2008) Phocidae of the Pliocene of Eastern USA pp: 81-14.

12. Scheel DM, Slater GJ, Kolokotronis SO, Potter CW, Rotstein DS, et al. (2014) Biogeography and taxonomy of extinct and endangered monk seals illuminated by ancient DNA and skull morphology. ZooKeys 409: 1-33.

13. Heptner VG, Chapskii KK, Arseniev BA (1976) Mammalia of the Soviet Union. Pinnipeds and Cetacea, Moscow: High School 2(3): 1-717.
14. Riedman M (1990) The Pinnipeds: Seals, Sea Lions, and Walruses. Berkeley: University of

15. Pierce G, Hernandez-Milian G, Santos M, Dendrinos P, Psaradellis M, et al. (2011) Diet of the Monk Seal (Monachus monachus) in Greek Waters. Aquatic Mammals 37(3): 284-297.

16. Koretsky IA, Domning DP (2014) One of the Oldest Seals (Carnivora, Phocidae) from the Old World. Journal of Vertebrate Paleontology 34(1): 224-229.

17. Rahmat SJ, Koper L, Crowell M, Alexander A, Koretsky IA (2017) Origin and Dispersal of True Seals Based on Recent Fossil Evidence. Society of Vertebrate Paleontology (SVP).

18. Ray CE, Bohaska D, Koretsky IA, Ward LW, Barnes LG (2008) Geology and Paleontology of the Lee Creek Mine, North Carolina, IV. Virginia Museum of Natural History, Special Publication.

19. Rahmat SJ, Koretsky IA (2018) Mandibular morphology of the Mid-Miocene seal Devinophoca claytoni (Carnivora, Phocidae, Devinphocinae). Vestnik Zoologii 52(6): 509-520. 